\title{
Applied Social Anthropology in the Researcher’s Own Society
}

\author{
Hans Petter Sand \\ University of Agder, Kristiansand, Norway \\ Email: hans.p.sand@uia.no
}

Received November 6 ${ }^{\text {th }}$, 2013; revised December $6^{\text {th }}$, 2013; accepted December $14^{\text {th }}, 2013$

\begin{abstract}
Copyright (C) 2014 Hans Petter Sand. This is an open access article distributed under the Creative Commons Attribution License, which permits unrestricted use, distribution, and reproduction in any medium, provided the original work is properly cited. In accordance of the Creative Commons Attribution License all Copyrights (C) 2014 are reserved for SCIRP and the owner of the intellectual property Hans Petter Sand. All Copyright (C) 2014 are guarded by law and by SCIRP as a guardian.
\end{abstract}

Professor Arne Martin Klausen (1927-) is the only social anthropologist in Norway who has tried to analyse the culture of the country as a whole. In doing this, he has explored several central themes of the country's culture; like egalitarianism, the class journey, the strong tradition for development aid to poor countries, connected to a so-called humanitarian super-power which in its turn was an extension of Christian mission, the very wide-spread newspaper reading; however self-centered to national and local issues and finally, the collision between an elitist Olympic culture with Norwegian egalitarianism. Klausen also tried to tie some threads together in editing a collection of essays on Norwegian culture.

Keywords: Configurations of Norwegian Culture; Biography of an Anthropologist; Both Modern and Traditional Society; Cultural Collisions

\section{Biography and Analysis of the Researcher's Own Society}

In Norway many social anthropologists have conducted research on small local communities in the country (e.g. Rudie, 1962; Brox, 1966; Bringslid, 1990). In later years most social anthropologists have been occupied with studying immigration.

But one social anthropologist has during most of his academic career been concerned with studying the Norwegian society in its totality. This is the now retired professor in this academic field, Arne Martin Klausen (1927-). As a starting point of my paper, I will take Klausen's autobiography: Et liv i kulturkollisjon (“A Life of Cultural Collisions”), 1999. In this book he writes that his own life from 16 to 25 years of age seemed to be a stronger collision of culture than his first meeting with an Indian village when he was 33 years old. He came from a small local community and had never been to the capital of Oslo before he came there as a student. He also maintains that in modern society with its enormous speed of change, a life course, like his own, may be experienced like a series of cultural collisions. In his autobiography he reflects about his own life course, from a working-class, puritan and fundamentalist religious childhood background, he has moved to a top academic position in social anthropology.

In his autobiography he refers especially to his works after 1984 as a project of grasping the whole society with concepts from social anthropology. However, in my reading of Klausen, I can trace an interest in society at large already from one of his earliest publications around 1960, and also through his Ph.D. dissertation published as a book in 1968. The author never makes these connections explicit, but I will argue that they can be read into an analysis of central cultural traits of Norwegian society.

Klausen's academic career ended up in a large, government sponsored research project trying to describe and analyze the social impact of the Winter Olympic Games in Lillehammer, Norway, in 1994.

It is also interesting to see that a younger, very prominent Norwegian social anthropologist, Marianne Gullestad (1946-), also has a project of describing and analyzing the whole Norwegian society. She starts from the point of view of everyday life and individual biographies.

\section{Configurations of Culture}

I will take as my point of departure the concept of configuration of culture developed by the American social anthropologist Ruth Benedict (1887-1948). She seems to understand this concept as a parallel to personality or character in psychology. The society, during its history, makes some choices that come to be characteristic of the way the society behaves. These characteristics are fairly stable over time, and represent the particularities of the society and its culture as compared to other societies and cultures.

\section{A Note on Biography}

Although Klausen never mentions it directly, his book may also be seen as a contribution to a now growing literature in Scandinavia on the so-called class journey. The term was first coined by the now retired professor of History of Ideas at the University of Umea, Sweden, Ronny Ambjornsson (1936-). In his book: Fornavnet mitt er Ronny ("My First Name is Ronny"), (2005), he looks critically upon his own development, from growing up in a one-room apartment in one of Stockholm's working-class areas, to a position as a professor at Umea and an intellectual career. The concept of class journey, is often connected to this book, at least in Scandinavia. The book was first 
published in Swedish in 1996.

The class society is not only about economy, according to Ambjornsson, it is first of all a cultural construction. The class journey goes through the social landscape, and is a problematic transition similar to the dilemma of the immigrant when it comes to identitity and belonging.

Aubert (1975) describes the class structure of Norway in a 150 years perspective. In the beginning of the $19^{\text {th }}$ century, Norway was a society with a small upper-class of state-officials and merchants with relatively high incomes and a very large proportion of common people; peasants, small-holders, servants and workers. The urban upper-class of state-officials consisted in 1825 only of 0.7 percent of the population.

When it comes to political influence, common people had from the mid $18^{\text {th }}$ century a comparably good standing. Many people, who stood outside the economic upper-class, had a right to vote and thus the possibilities to influence political decisions. Compared to other European countries the egalitarian element in politics was strong from 1814 and onwards. Norway got a comparably democratic constitution in 1814. This in turn is connected to other egalitarian elements in Norwegian society at that time. There was no landed aristocracy nor any large agrarian proletariat. There were many small self-owning farmers and relatively modest differences between self-owners, tenants and small-holders in many parts of the country. This meant that at least one foundation for class-division, that had played a very large role in many other European countries, was of less importance in Norway. Especially for the relations of authority, this was crucial.

The class structure was not the same all over the country. The class-differences and the class-contradictions were significantly larger in the rural areas of Eastern Norway than they were in Western Norway. In Northern Norway a large part of the fishing population were under a kind of feudal system with marked class differences. Nobility was abolished in 1821. Although this was not much more than a formal confirmation of an already existing condition, it implied the removal of the formal norms confirming the faith in superior social abilities as inborn. The norms about power and prestige regarding the relations between a land-owning aristocracy and an agrarian proletariat have found less support in Norway than in most European countries.

These trait of Norwegian society has been strengthened by the political mobilization of the farmers from the late $19^{\text {th }}$ century, and then in the political mobilization of the workers, small farmers and fishermen during the $20^{\text {th }}$ century. William Lafferty (1983) has termed the Norwegian state of the second half of the $20^{\text {th }}$ century "the social-democratic state". However, the foundation for this state had been laid by the political mobilization of the farmers. Lafferty has emphasized the ability of this state for democratic mobilization and pragmatic reforms for greater social and economic equality.

So, to me, it seems natural that the interest in the class journey has been great in Norway, and that also Klausen autobiography can be seen in this context. He recalls that to his working class parents, an education after seven years of compulsory schooling, was unthinkable. He writes, in a tone of regret, that all his siblings have done well and adapted to the social environment that he himself did not manage to adapt to.

I will now turn to Klausen's academic writing and show how he all through his career has been occupied with different central traits of the Norwegian cultural configuration, and more and more reaching a more comprehensive picture.

\section{The Protestant Ethic}

The Norwegian version of the protestant ethic and the spirit of capitalism (Weber, 1995), came with the so-called haugianism or The Hauge Movement (Jonassen, 1947). The farmer's son, Hans Nielsen Hauge (1771-1824), had a mystical experience in 1796 and decided to become a lay Christian preacher. Parallell to his preaching he established small businesses and encouraged his followers to do the same. The haugians as they have been called, should not be "of the World", but behave actively "in the World". They argued that God had put them on earth to work, govern and use the worldly activities for the salvation of their souls. This religious awakening therefore always went together with a demand for work as a worldly calling. By ascetic life and inner solidarity the haugians became a strong and visible element of economic life in the first half of the $19^{\text {th }}$ century.

Klausen grew up in a lay Christian organization that can be said to be one of the heirs of the haugianism. His father was a member of the council of elderly in this organization called The Free Church. He had a much respected position, but was regarded as a very strict man. Klausen writes (1999: p. 40):

"My childhood environment and my upbringing gave me early a feeling that we stood outside the ordinary society. We were something of our own. Movies, theatre, dancing and sport, of course, were taboos. What felt most troublesome, however, was the feeling of inferiority that was created through a systematic stressing of modesty and submissiveness. We should not think that we had anything to be proud of if it was not of the grace of God. In ourselves we were nothing" (my translation).

Gradually, however, Klausen broke with his strong puritanic religious background. It may be symptomatic that one of his first academic works represented an analysis of the hidden power structures of The Free Church, and he states that this study partly was based on participant observation (Klausen, 1960).

\section{Kerala Fishermen}

The Norwegian development aid project to improve fisheries in Kerala, India, was started in 1953, and was, at that time, a very ambitious enterprise. Klausen did fieldwork for about one year on the project from 1960 to 1962, and found great differences in how the various groups of population in the area reacted to the aid. While the Catholic fishermen relatively rapidly adapted to motor boat fishing, the Hindu fishermen of the Araya caste, to a great extent sold their motor boats to the Catholics and returned to their traditional fishing with canoes.

My point here, is not the study in itself, but the fact that Klausen also here, as in the case of the protestant ethic, touches upon a theme that is central to the Norwegian cultural configuration, namely a strong emphasis on Christian mission. This Christian mission has in the post-war period been extended into state-financed development aid and also a gradual transfusion of Christian mission and state-finances development aid.

Galtung and Gleditsch (1975) thus characterizes Norway as a very moral country. By this is meant that political and personal decisions often are formulated as moral questions, and not as question about suitability or utility. The intense religiosity in Norway, compared to its neighbouring countries, is a sign of 
this, as well as influence of religion on politics in questions of temperance, abortion and pornography. Even though the main dimension of Norwegian politics is the division between right and left (which mainly is a question about social and economic differences), the strong position of the parties in the center (The Christian Party, The Liberal Party) is an expression of the great role moral questions like religion and temperance plays in politics in the country. This line of division has often been named the moral-religious dimension in Norwegian politics, or a division between center and periphery, the periphery being the southern and western parts rooted in haugianism (e.g. Martinussen, 1975).

Norway has also been characterized as puritanic and modest, another expression of the emphasis on the moral dimension (Galtung \& Gleditsch, 1975). These are, naturally, classical capitalist virtues and has often been seen as a condition for saving and investment that has been the driving force of the economic development in the West in modern time. But economic prosperity often leads to a disappearance of these virtues. This, however, seems to be, to a lesser degree the case in Norway. The Norwegian way of enjoying life is to a larger degree connected to relativedly simple pleasures, like for instance experiencing nature, and to a lesser degree connected to material consumption.

Terje Tvedt (2002) has analyzed the Norwegian self-image of being a humanitarian super-power. He point primarily to the country's great ambition concerning development aid to poor countries. He also show how this image has become a part of the intellectual discourse within the country, so that there is no critical voice. His conclusion is as follows (2000: p. 192):

"World views have led people to the trenches before, do so today, and will do it tomorrow. Even though Norwegian world views only have limited significance for the development of the world, they are always important in Norway, and since Norway works for development in more than a hundred countries and aspires to be a humanitarian super power, they are not unimportant in other contexts.

I have tried to show how hegemonic conceptions have dominated those whose self-declared role is to unveil the dominant conceptions. This has led to a national process of formation that continually has prevented the development of a tradition of knowledge with a clearer view both of the world and ourselves. The intellectual tradition that I have analyzed, has not been able to promote a public, rational and knowledge-based discussion about Norwegian politics in the global arena. It has been dominated by a way of thinking that has pretended to be universalistic, but has mistaken a particular tradition with the tradition of all human beings, and which has insisted upon describing the world, but has described it as a cloning of itself. It is thus talk of a curious, contradictory phenomenon: the intellectual as a cosmopolitan, but as a narcissistic cosmopolitan; a figure that had the best of intentions, but did not have the ability either to see "the other" nor "himself" in their humanity—as real historical subjects” (my translation).

\section{The Norwegian Way}

Norway was actually a colony under Denmark from 1536 to 1814. In 1814 Norway was, as a result of Denmark being on the losing side after the Napoleonic wars, seceded to Sweden. However, in a short period in 1814, a Norwegian elite managed to build a liberal constitution influenced by the French and
American ones. Norway then entered into a union with Sweden and was allowed to keep the constitution only with some adjustments. A national movement swept the country in the second half of the $19^{\text {th }}$ century. This movement went together with rapid modernization, democratization and struggle for independence from Sweden. Independence was attained in 1905, and the centennial is celebrated these days.

In the winter of 1982, The Norwegian Association of Social Anthropologists organized a conference at Finse. Finse is a station on the railway between Oslo and Bergen, and is the highest point of this railway, 1222 metres above sea level.

The papers at the seminars were published in a book with the title: Den norske vaerematen. Antropologisk sokelys pa norsk kultur ("The Norwegian Way. Anthropological Focus on Norwegian Culture”), 1994. The book was edited by Arne Martin Klausen. He recalls in his autobiography, that to the great surprise of the contributors, the book became a great success. It was reviewed in almost every little newspaper all over the country, and Klausen had the feeling that he had never been so much in the media as when the book had been published. The reception of the book was interpreted as an expression of something central to Norwegian culture, namely self-centeredness.

Among academics the book got a mixed reception. The main criticism was that the book had been too little anchored in thorough field work, and thus contained a lot of speculation about the distinctive character of Norway. Others criticized the book for consolidating stereotypes and downplaying both ethnic and class differences.

The social anthropologists who wrote the book, noted that Norway appeared like a local community writ large, a somewhat anachronistic rural district with strong egalitarian norms and programmatic demands for being genuine and serious. And the Norwegians' relation to nature takes on an existential dimension. This would be alien to urbanists elsewhere.

These characteristics may be founded on some elementary facts about the country. Norway is a country with a small and scattered population, a limited urban tradition, a history of coexistence with dominating neighbours, Denmark and Sweden, and a society without a nobility and with few formalized privileges.

To professor of political science at the University of Oslo, Oyvind Osterud (1986), the anthropologists' search for the national characteristics, is more of a reflection that these traditional ways are undergoing transition.

\section{The Tabloid Paper}

The Norwegian population are "world champions" of reading newspapers. Nine out of ten inhabitants of Norway read one or more newspapers every day (Lundby, 2003). This figure has kept stable, although there has been a slight decrease in recent years. However, only a few of the newspapers are nation-wide, most are locally or regionally oriented. This fact point to the self-centredness of Norwegian society.

In the beginning of 1982 there were rumors that the newspaper "Dagbladet", similar to its competitor VG in sale of single copies newspapers in Norway, would change format and turn into a tabloid paper. In many peoples' view Dagbladet was the cultural newspaper par excellence in Norway, and taboid paper was not only a format, but gave associations to commercialism, scandals and sensations. A hundred Norwegian intellectuals 
signed an appeal that the leaders of Dagbladet knew their responsibility and did not let the newspaper decay into a market product, but still could be a spokesman for good intellectual life in the country. Klausen felt this appeal quite exotic and it aroused his curiosity. His commitment to the study of Norwegian culture, made him decide to study the transition of Dagbladet to a tabloid paper. In November 1982, five months before the transition to tabloid paper, he set out with his field work in the newspaper. During a period of three years Klausen did his field work one day a week in the newspaper.

In 1986 Klausen published his findings in a book named: Med Dagbladet til tabloid-En studie i dilemmaet bors og katedral, ("With Dagbladet to Tabloid Paper-A Study in the Dilemma "Stock Exchange and Cathedral").

His main conclusions were that the format of taboid paper in itself did not represent any dramatic change. But in the planning phase the leaning toward the market was more pronounced than what became reality after some time. The feature article, for instance, that had been planned to be left out, was kept. Klausen's main point was that Dagbladet followed a general development in the media that implied a tougher commercialization and market-orientation.

Despite the fact that the change did not become as drastic as was feared by the opponents, some of the opponents set out a boycott of the newspaper. The most active one was Johan Galtung, who wrote an article called "Dagbladet in memoriam". It was a funny recipe of a cure against reading Dagbladet. Galtung is still the only one who never returned to the paper as a writer.

\section{The Olympic Games as Modern Ritual}

In 1994 the Winter Olympic Games were to take place in Lillehammer, a small town north of Oslo, with long traditions for winter sports and with a good winter climate for such activities.

Klausen set out to gather a group of social anthropologists to study the Winter Olympic Games from a socio-cultural point of view. The group got a grant from the Norwegian Government of about 400,000 dollars.

In his studies of sport history and particularly the history of the Olympic Games, Klausen (1999) found that Baron Pierre de Cobertin, who recreated the Olympic Games, belonged to a fascinating circle of personalities in Paris. In the circle one could find, Emile Durkheim, often called the father of sociology, Frederic Le Play, a well known reformer and social researcher and several famous artists. They were all romantically inspired by the classical Greek culture. More important, however, they looked upon the development of society with worry. They were worried about what Durkheim called anomie, or the dissolution of the web of society. They had a solid bourgeons anchoring and stood in opposition to the socialist, revolutionary social research and politics of Marx. But they were also, like the socialists, fundamentally optimists of development. Klausen terms them "men of the modern break through".

Coubertin wanted to introduce the British school system and the British sport in French school as some sort of universal remedy. This was his main project. To recreate the Olympic Games was secondary.

The World Exhibition in Paris in 1889 became a powerful inspiration to Coubertin. This was especially the case with the Eiffel Tower, the symbol of the limitless technological opti- mism of development and faith in the future. Several of the Olympic Games, thus were set up as a kind of appendix to the World Exhibitions.

In Klausen's view there was at an early time a solid coupling between the Olympic sport and modern technological capitalism and commercialism. This coupling has grown stronger and stronger. There is thus no break in the Olympic ideology, the Olympic ideology has for a hundred years been the supporter of modernity.

The Olympic movement can be seen as a solid, conservative, idealist variant of modernity that most people in our part of the world are sympathetic to and active supporters of.

To Klausen, Coubertin's special gift was to see the human body as a general symbolic arsenal for the limitless optimism of development.

The research of Klausen and his associates was based on general ritual theory. In an anthropological perspective rituals are conventionalized, repeated acts that particularly occurs in two contexts; in connection with institutions of power and authority, and through life-crises from birth to examinations, weddings and funerals. In such situations the rituals have an educational function with their conventionalized and often artistic form of language forge into people fundamental cognitive conceptions and values of society.

Klausen points to that ritual forms have an ability to survive with new contents in social change. In modern society the pace of change is enormous. We cherish everything that involve change, criticism and exceeding of taboos, creativity and the breaking of limits in art, science and technology. Modern society is a society without a center and seemingly without absolute authorities.

The kind of rituals best suited to express such fluent values are, according to Klausen, rituals like the Olympic Games. Such rituals must be potentially ambiguous and common to all people at the same time. They must also in their form be in accordance with something limitless and transcendent.

The Olympic Games are, according to Klausen, ambiguous, have many functions, and they give opportunity for all sorts of interest groups to demonstrate. A lot of groups actually used the Olympic Games as an arena for fight and demonstrations.

The Olympic Games are also characterized by the spectacular, the limitless, what transcends what people have experienced before, and the visual part plays a main role. The Olympic Game thus have to transcend the foregoing. Higher, faster and stronger is the core rhetoric in the Olympic ideology. The Olympic Games are thus, according to Klausen, more and more a ritual expression of modern optimism of development.

\section{Lillehammer Olympic Winter Games and Norwegian Society}

Klausen anticipated, from his analysis of the Olympic Ritual, that it would lead to cultural collisions in a small Norwegian town. He thus maintains (1999: p. 263):

"My earlier studies of Nowegian culture and distinctive character, supported by several foreign researchers that have studied us, has given me the understanding that Norway-despite being a modern industrial nation - we still carry with us traits from the pre-modern, small-scale society. The German author Hans Magnus Enzensberger, who has lived in Norway for a long time, named his book about us Norsk Utakt (Norway Out of Time"), thus indicated that we are out of time with the 
modern mainsteam of Europe. In all of our rhetorics we express that we are the keepers of the best democratic qualities, like for example egality, solidarity and collective decision-making, the opposite of individual competition in a hierarchical class-society, private enterprise and exclusive concentrations of power".

The first clash between Olympic culture and Norwegian culture, was a public debate whether Norway could afford the form of luxury the games would imply.

Then there was a clash between Norwegian sport, which is to a large extent democratic and voluntary and the IOC (International Olympic Committee) connections to big capital and an aristocratic life style. This debate was in the media thus called the "debate of snobs", because some members of the organizing committee had behaved snobbish and extravagantly in the small town of Lillehammer.

When the volunteers had been recruited, an organizational psychologist represented them with a strong critique of what he argued was an authoritarian and militarist attitude towards the volunteers. This critique is in line with the pattern of opposistion between the modern, effective organization versus the popular, democratic Norwegian values.

The publishing of the book Lords of the Rings in 1992, led to a stronger opposition against the IOC-leaders. Towards the opening of the Olympic Games in 1994, Norwegians discussed how they should behave towards IOC and its president Juan Antonio Samaranch, whose fascist background had been revealed.

The most popular Norwegian sportsman, the cross country skier, Vegard Ulvang, spoke critically to the press about IOC. Ulvang was the man who was to take the oath at the opening of the games.

However, as Klausen mentions, it is interesting to see that Ulvang's critique first and foremost aimed at the problem that non-professional sportsmen got more and more influence and dominance over the resources of the IOC. Han had no fundamental criticism against modern elite sport and the commercialization if it.

This type of criticism seems to be in line with typical Norwegian values and relates to lack of democracy in the IOC.

All inn all, the IOC met en unexpected critical attitude in Norway, apparently to their surprise and irritation. It became so dramatic that some threatened to leave Lillehammer and some meant that Ulvang should be removed from the games.

So, a lot of Norwegian sport leaders had to try to calm down the heated athmosphere.Also the state minister had to take part in this work of calming down the athmosphere. She gave a message to the Norwegian people through the television where she declared:

"I think we shall state the fact that we arrange these games in a Norwegian style. Still we are on an international arena, we have taken on to be hosts, and there are not only socialdemocrats and Norwegians around the world...We Norwegians are more used to a mentality of egality than perhaps no other country, and that is really a fine ting about our culture and environment” (quoted after Klausen, 1999: p. 266).

To the closest associates of Samaranch, the Norwegian reactions represented an unprecented lack of politeness and gratitude. The director general of the IOC stated the following to one of the largest newspapers in Norway (VG):

"IOC do not care about what Norwegians think. What points of view four million people in a small province of Europe have of IOC, we do not care about. There are several hundred peo- ple worldwide who support IOC and receive us well" (quoted after Klausen, 1999).

The Olympic games were also used to mobilize for humanitarian action to Sarajevo,which had been the host of the games in 1984, and now was in a situation of war. The peace perspective and the Norwegian practice of collecting money all over the country for humanitarian purposes thus became an additional feature of the Olympic Games.

\section{What Did the Olympic Games Do to Norway?}

In a conference at Lillehammer in 1989, sociologist Gudmund Hernes, tried to sum up the ideas of how to use the Olympic Games to make Norway more known in the world. He began stating that Norwegians are a quarrelsome people, but peaceful to the rest of the world because they like to quarrel among themselves. He claimed that if Norwegians really had believed they would get the Olympic Games, the opposition within the country would have been so great that the games would never have taken place. This had to do with the fact, according to Hernes, that for Norwegians it is easier to mobilize objections than enthusiasm. However, he also pointed to a long tradition for cooperation and used the Vikings as an example; in war they tied their ships together to better behave coordinated.

To Klausen this conception of Norwegian society supported many other analyses: The society is among the top as to standards of living with a large degree of social equality and selfrespect. And the society is open: where you end up is in no way connected to descent or rank. The political system builds on participation, equal opportunities, breadth and participation. Hernes summed up with an appeal to market these values and do it with pride and self-consciousness.

However, Klausen point to the fact that Norwegians do not unambiguously support these evaluations. Many of those stereotypes that are emphasized as the best traits of the Norwegian cultural tradition; ideology of equality, participatory democracy, local belongingness, these traits are by some regarded as negative and reactionary. It is interesting to note that a couple of these democratic values in Norwegian language have got strong negative metaphorical concepts. "Janteloven" (a ten point "law" about the strong social control in the small communities, originally conined by a Norwegian author) make fun of and perverts the ideology of equality. "Nisseluementalitet" (red stocking cap mentality) is the corresponding concept for the value of local belongingness and self-consciousness.

During the Winter Olympic Games another saying was created by the managers of the games: "Norway is a country of four million consultants". This saying was used with a negative connotation and as an explanation of criticism and a desire for transparency of decision making and joint consultations.

Klausen's conclusion seems to go in this direction:

The Lillehammer Olympic Games led to greater pride in traditional Norwegian cultural traits, but at the same time it brought the country more in line with the "main-stream trends" in the part of the world that rule the global development.

\section{Conclusion}

I have tried to show how a social anthropologist has had as his life project to describe and analyse the cultural configuration of his own country. I have done this by referring to other social scientists and writers who have treated the same central 
characteristics of Norwegian culture and society. Also, I have argued that Klausen, coming from a working-class and religious puritanical background and entered into a top position in Norwegian academic life, has become particularly sensitive to these central traits of his own society. His professional life can be seen as an ongoing field-work of Norwegian society.

\section{REFERENCES}

Allden, L., Rogoff Ramsoy, N., \& Vaa, M. (1986). Det norske samfunn ("Norwegian Society"). Oslo.

Ambjornsson, R. (2005). Fornavnet mitt er Ronny ("My First Name is Ronny”). Oslo.

Aubert, V. (1975). Sosiale klasser og lag (“Social Classes and Stratas”). In Ramsoy and Vaa (Eds.), Oslo.

Benedict, R. (1932). Configurations of culture in North America. American Anthropologist, 34.

http://dx.doi.org/10.1525/aa.1932.34.1.02a00020

Benedict, R. (1989). Patterns of culture. New York: Houghton Mifflin Harcourt.

Benedict, R. (1989). The chrysanthemum and the sword: Patterns of Japanese culture. New York: Houghton Mifflin.

Berntsen, H. (2001). UT. Fra en oppvekst i forrige arhundre ("OUT. On Growing Up in Last Century”). Oslo

Bringslid, M. B. (1990). "Home Parties" i Sommarfjord ("Home Parties in Summerfjord"). Oslo

Brox, O. (1966). Hva skjer i Nord-Norge? En studie I norsk utkantspolitikk ("What is Happening in Northern Norway? A Study of Norwegian Regional Policy"). Oslo.

Frones, I., \& Kjolsrod, L. (2003). Det norske samfunn ("Norwegian Society”). Oslo.

Galtung, J., \& Gleditsch, N.P. (1975). Norge i verdenssamfunnet ("Norway in the World Society"). In Ramsoy and Vaa (Eds.), Oslo.

Gilje, N. (1994). Hans Nielsen Hauge og kapitalismens and ("Hans Nielsen Hauge and the Spirit of Capitalism”). Bergen.

Gilje, N. (1995). Haugebevegelsen og sekulariseringens dialektikk ("The Hauge Movement and the Dialetics of Secularization"). In S. A. Christoffersen, \& T. Wyller (Eds.), Arv og utfordring. Oslo: Universitetsforlaget.

Gullestad, M (1984). Kitchen-table society. Oslo: Universitetsforlaget.

Gullestad, M. (1985). Kultur og hverdagsliv. Verdier,selvforstaelse og samfunnssyn i det moderne Norge ("Culture and Everyday Life. Values, Self-Understanding and View of Society in Modern Norway"). Oslo.

Gullestad, M. (2002). Det norske sett med nye oyne. Kritisk analyse av norsk innvandringsdebatt ("Norwegian Life Seen with New Eyes. A Critical Analysis of Norwegian Debate on Immigration”). Oslo
Jonassen, C. T. (1947). The protestant ethic and the spirit of capitalism in Norway. American Sociological Review, 12. http://dx.doi.org/10.2307/2086953

Klausen, A. M. (1960). Social organization in a Norwegian Religious Community. Journal of Social Research, Oslo.

Klausen, A. M. (1968). Fiskere i Kerala. En norsk etnografs skildrer to fiskelandsbyers forste mote med motoralderen ("Kerala Fishermen. A Norwegian Ethnographer Describes two Fishing Villages First Meetin the Age of Engines"). Oslo.

Klausen, A. M. (1984). Den norske vaerematen. Antropologisk sokelys på norsk kultur ("The Norwegian Way. Anthropological Searchlight on Norwegian Culture”). Oslo.

Klausen, A. M. (1986). Med Dagbladet til tabloid.En studie i dilemmaet "bors og katedral" ("With Dagbladet to Tabloid. A Study of the Dilemma "Stock Exchange or Cathedral"). Oslo.

Klausen, A. M. (1996). Lillehammer-OL og olympismen. Et moderne rituale og en flertydig ideologi ("Lillehammer Olympic Games and the Olymism. A Modern Ritual and an Ambiguous Ideology”). Oslo.

Klausen, A. M. (1999). Et liv i kulturkollisjon ("A Life in Cultural Collisions”). Oslo.

Lafferty, W. (1983). Leftist and rightist ideology in a social democratic state. Oslo.

Lundby, K. (2002). Mediefeltet-Kampen om oppmerksomheten ("The media field-The struggle for attention”). In Frones, \& Kjolsrud (Eds.), Oslo.

Martinussen, W. (1975). Politiske skillelinjer og politisk deltakelse (“Political Divisions and Political Participation”). In Ramsoy, \& Vaa (Eds.), Oslo.

Osterud, O. (1986). Nasjonalstaten Norge—En karakteiserende skisse ("The Norwegian nation state-An outline”). In Allden, Ramsoy, \& Vaa (Eds.), Oslo.

Petterson, P. (2004). Manen over porten ("The Moon Above the Gate"). Oslo.

Rogoff Ramsoy, N. (1968). Det norske samfunn (“Norwegian Society”). Oslo.

Rogoff Ramsoy, N., \& Vaa, M. (1975). Det norske samfunn (“Norwegian Society"). Oslo.

Rudie, I. (1962). Endring i et marginalt samfunn ("Change in a Marginal Community"). Oslo.

Seljestad, L. O. (2002): Blind. ("Blind”), Oslo

Simon, V., \& Jennings, A. (1992). The lords of the rings: Power, money and drugs in the modern Olympics. London: Stoddart.

Sveen, K. (2000). Klassereise. Et livshistorisk essay ("Class Journey. A Biographical Essay"). Oslo: Forlaget Oktober.

Tvedt, T. (2002). Verdensbilder og selvbilder. En humanitar stormakts intellektuelle selvbilde ("World Images and Self Images. The In- tellectual Self Image of a Humanitarian Super Power”). Oslo. 